\title{
Zastosowanie naturalnej luminescencji do wykrywania radionuklidów w produktach spalania węgla kamiennego
}

\begin{abstract}
Streszczenie. W pracy podjęto próbę określenia możliwości wykorzystania zjawiska naturalnej luminescencji materii do wykrywania radionuklidów w produktach spalania wegla kamiennego. Do eksperymentu użyto stacji pomiarowej wyposażonej w fotopowielacz do identyfikacji i zliczania fotonów emitowanych przez wzbudzoną materię. Proces pomiaru liczby emitowanych fotonów przeprowadzono automatycznie, z użyciem środowiska programistycznego LabView. Odnotowano różnicę w liczbie fotonów w badanych grupach produktów spalania węgla, stwierdzenie to dotyczy produktów końcowych i składników tworzących ich mieszaniny. Zaobserwowano, że istnieje praktyczna możliwość różnicowania produktów spalania węgla kamiennego pod względem poziomów emisji fotonów.

Abstract. The research attempts to determine the possibility of using the phenomenon of natural luminescence of matter to evaluate the radionuclide transfer pathway in coal combustion processes. For the experiment, a measuring station equipped with a photomultiplier was used to identify photons emitted by optically piqued matter. The process of measuring the number of photons emitted was performed automatically, to which the LabView programming environment was used. There was a difference in the number of photons within the tested groups of coal combustion products, this statement concerns the final products and components constituting their mixtures. It has been observed that there is a practical possibility of differentiating matter in terms of photone emission levels. (The use of natural luminescence for the detection of radionuclides in hard coal combustion products).
\end{abstract}

Słowa kluczowe: fotony, luminescencja, węgiel, spalanie

Keywords: photons, luminescence, coal, combustion

\section{Wstęp}

Radionuklidy to pierwiastki promieniotwórcze, które dzielą się na dwie główne grupy. O przynależności pierwiastka do danej grupy decyduje jego pochodzenie. Do pierwszej grupy radionuklidów, zalicza się pierwiastki powstałe podczas formowania się układu słonecznego. Ich cechą charakterystyczną jest długi czas połowicznego rozpadu wynoszący co najmniej $5 \cdot 10^{9}$ lat $\left({ }^{235} \mathrm{U},{ }^{238} \mathrm{U},{ }^{232} \mathrm{Th}\right)$. Do drugiej grupy pierwiastków promieniotwórczych zaliczane są wszystkie izotopy, które powstają w wyniku przemian pierwiastków znajdujących się w powietrzu atmosferycznym pod wpływem np. działania promieniowania kosmicznego (np. $\left.{ }^{3} \mathrm{H},{ }^{7} \mathrm{Be},{ }^{14} \mathrm{C}\right)[1]$.

Węgiel kamienny jest najstarszym wykorzystywanym źródłem energii na świecie. Pomimo generowania wielu problemów środowiskowych związanych z jego pozyskiwaniem i spalaniem jest nadal popularniejszy niż gaz ziemny, ropa naftowa, energia jądrowa, wodna i odnawialna. Energia elektryczna wytwarzana z węgla kamiennego stanowi około $40 \%$ produkcji światowej. O zachowaniu się węgla $w$ procesach spalania decyduje obecność pierwiastków takich jak wodór, azot i siarka [2].

Węgiel kamienny najczęściej powstaje $\mathrm{z}$ torfu $\mathrm{w}$ procesach kompresji i przebudowy strukturalnej. Transformacja materii organicznej do węgla kamiennego jest dwuetapowa - biochemiczna i fizykochemiczna. Powstawanie węgla jest zawsze poprzedzone procesem torfowania, a następnie grafityzacją [3,4]. Etap fizykochemiczny rozpoczyna się po zakończeniu rozkładu mikrobiologicznego materii organicznej w torfowiskach. Głównymi czynnikami działającymi na materię podczas fazy fizykochemicznej i wpływającymi na powstawanie węgla są temperatura, ciśnienie, objętość i czas. Temperatura jest uważana za kluczowy czynnik przy powstawaniu pokładów węgla kamiennego. Jej wzrost przyspiesza reakcje chemiczne podczas uwęglania materii w torfowiskach $[4,5,6]$. W miarę postępowania procesów uwęglania następuje progresywna transformacja złoża torfu, zwiększając proporcję węgla w stosunku do zawartości tlenu, substancji lotnych oraz wody (tzw. uwęglanie materii).
Zwiększanie nacisku warstw pokrywających torfowisko (zagęszczanie przez cały czas nadbudowujący się nadkład) wpływa na rodzaj powstającego węgla - najpierw materia organiczna będzie konwertowana w węgiel brunatny, a następnie w antracyt - węgiel kamienny [7].

Węgiel kamienny (lub twardy), ze względu na materiał z którego powstaje, zawiera w swojej strukturze mineralogicznej naturalne izotopy promieniotwórcze. Stężenie poszczególnych izotopów zależy od skał towarzyszących, w których formuje się pokład węgla. Ich podstawowym źródłem są fosforany, monacyt, cyrkon, ksenotym i uranothoryt. W węglach kamiennych wydobywanych na obszarze Górnego Śląska spotykane są naturalne radionuklidy należące do szeregu promieniotwórczego ${ }^{238} \mathrm{U} \mathrm{i}^{232} \mathrm{Th}$. Ich średnia zawartość $\mathrm{w}$ pokładach węgla kamiennego kształtuje się na poziomie 18 i $11 \mathrm{~Bq} \cdot \mathrm{kg}^{-1}[8,9]$.

Monitorowanie emisji radionuklidów jest jednym z parametrów pozwalających na określenie zagrożenia dla zdrowia ludzi przez odpady powstające w procesach spalania węgla kamiennego. Popioły lotne zazwyczaj zawierają wyższe zawartości radionuklidów, takich jak uran, tor i potas, które stanowią potencjalne zagrożenie dla zdrowia ludzi poprzez emisję promieniowania jonizującego. Wykorzystanie popiołów w przemyśle cementowym oraz w budownictwie (np. materiały budowlane, cegły betonowe, kleje, materiały tynkarskie) mogą zwiększać stężenie izotopów promieniotwórczych w powietrzu wewnętrznym ponad dopuszczalne poziomy. Problem ten jest najbardziej widoczny w nowych budynkach lub obiektach o niskim stopniu wentylacji. Pomiary radioaktywności w budynkach najczęściej przeprowadza się za pomocą spektrometrii promieniowania gamma. Dodatkowym wskaźnikiem określanym dla oceny wpływu ekspozycji człowieka na promieniowanie jest dawka efektywna $[10,11,12]$

F. A. Popp [13] rozwinął koncepcję, w której założył że każdy materiał powstały $z$ materii organicznej emituje specyficzne promieniowanie elektromagnetyczne. Jest ono obserwowane w zakresie długości fal od 300 do $800 \mathrm{~nm}$, przy występowaniu koherentności promieniowania. Pomiar 
emitowanego światła przez materiał organogeniczny przeprowadza się najczęściej w zakresie światła widzialnego przy zachowaniu czułości widma powyżej 10 W. Wysoka czułość pomiaru po wzbudzeniu próbki wiązką światła pozwala wychwycić fotony, które są cząstkami elementarnymi nie posiadającymi ładunku elektrycznego oraz masy spoczynkowej. Zaobserwowanie zbioru fotonów w polu magnetycznym o wysokiej częstotliwości może stanowić wskaźnik toksyczności materiału dla środowiska $[14,15]$.

Pionierem w zakresie luminescencji minerałów kopalnych jest zespół amerykańskich naukowców pracujących pod przewodnictwem L. M. Coyne'a. W swoich badaniach wykazali, luminescencja może być indukowana $\mathrm{w}$ minerałach $\mathrm{m}$. in. podczas odwadniania w temperaturze pokojowej lub podczas łagodnego ogrzewania próbki. W sporadycznych przypadkach może być związana $z$ wyparciem wody przez stosowanie rozpuszczalników aminowych. Coyne podczas badań określał uwolnienie fotonów, które były obserwowane przez układy optyczne jako opóźniona eksplozja światła związana z napięciam generowanymi wewnątrz struktur krystalicznych różnych minerałów [16] - [18].

Odwodnione zawiesin węgla w temperaturze pokojowej, ekstrakty węgla oraz popioły węglowe powoduja spontaniczną luminescencję. Zjawisko to charakteryzuje się monotonicznym zanikiem aktywności fotonu, który jest poprzedzony jego gwałtownym wzrostem uwalniania. Maksimum emisji zostaje osiągnięte zazwyczaj w ciągu pierwszych minut pomiaru. Wielkość aktywności fotonów jest poważnie ograniczona przez uziarnienie węgla. Wcześniejsze usuwanie substancji mineralnych z węgla ogranicza zjawiska luminescencji, co sugeruje, że gliny lub materia organiczna wykazuje interakcje wewnątrz struktury krystalicznej węgla [19].
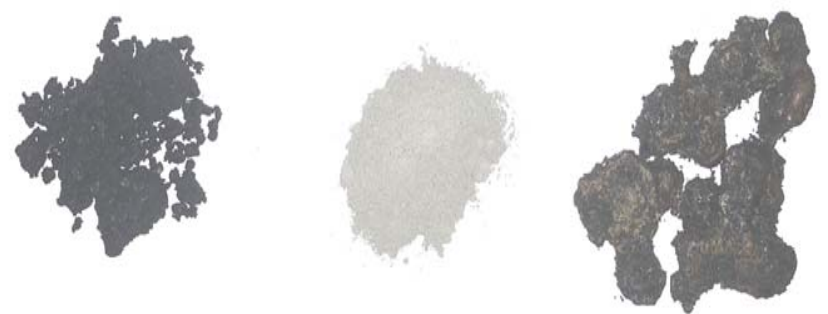

Rys. 1. Analizowane próbki (od lewej: węgiel kamienny, popiół, żużel)

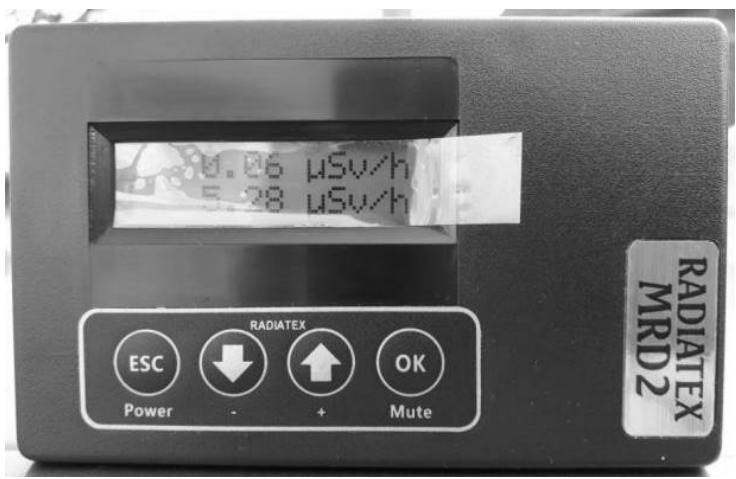

Rys. 2. Radiometr MRD-2

\section{Metodyka badań}

Do badań wykorzystano próbki węgla kamiennego pochodzącego z kopalni zlokalizowanej w Górnośląskim Zagłębiu Węglowym. Przed badaniem, próbka została zmielona do postaci analitycznej 0,2S zgodnie z PN-G 04502:2014-11. Przygotowane próbki węgla zostały spopielone zgodnie z wymogami PN-ISO 1171:2002. W celu otrzymania próbek żużla próbki pierwotne węgla kamiennego zostały poddane procesowi spalania w temperaturze $1100^{\circ} \mathrm{C}$ w piecu muflowym (Rys. 1.).

Badanie emisyjności radionuklidów w poszczególnych próbkach wykonano $\mathrm{z}$ wykorzystaniem urządzenia dozymetrycznego MRD-2 firmy Radiatex (Rys. 2). Zasada działania urządzenia opiera się na pomiarze intensywności radiacji elektromagnetycznej, którą wywołuje promieniowanie jonizujące w czasie 120 s pomiaru.

Badanie naturalnej luminescencji próbek wykonano $z$ wykorzystaniem stanowiska badawczego wymuszającego postać strumienia świetlnego o sklasyfikowanej długości fali. Do analizy wykorzystano autorskie stanowisko pomiarowe mierzace promieniowanie elektromagnetyczne emitowane $z$ analizowanego materiału (rys. 3). Do rejestracji sygnału wykorzystano detektory $R$ 1538-13 wyposażone w układ wzmacniający sygnał fotopowielacza. Zadaniem fotopowielacza jest zamiana impulsu świetlnego na sygnał elektryczny kierowany do dyskrymiantora progowego. W dyskryminatorze sygnał elektryczny jest konwertowany na impulsy logiczne przewyższające zadaną amplitude progowa. Sterowanie układem pomiarowym odbywa się za pomocą środowiska LabVIEW 2015.

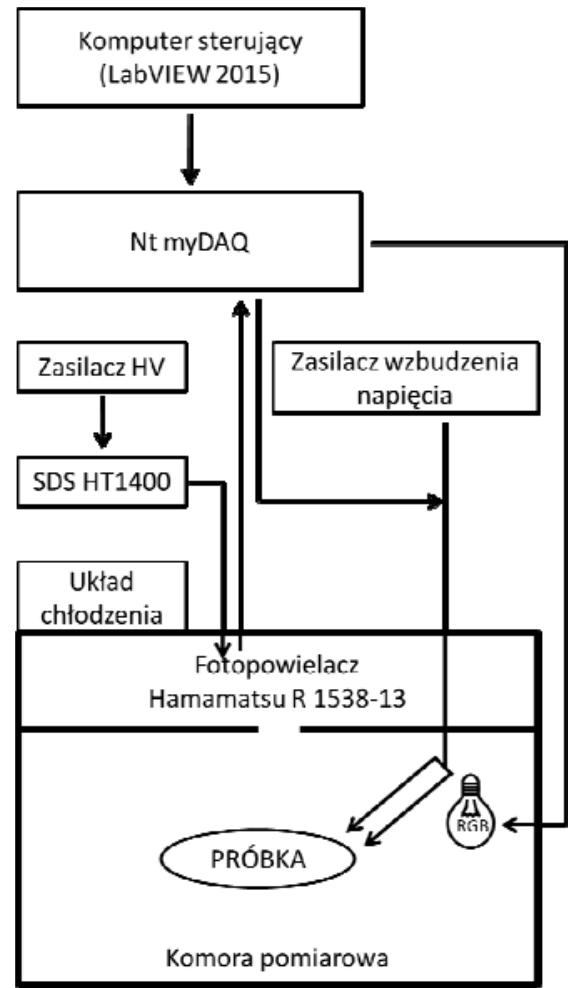

Rys. 3. Schemat układu pomiarowego

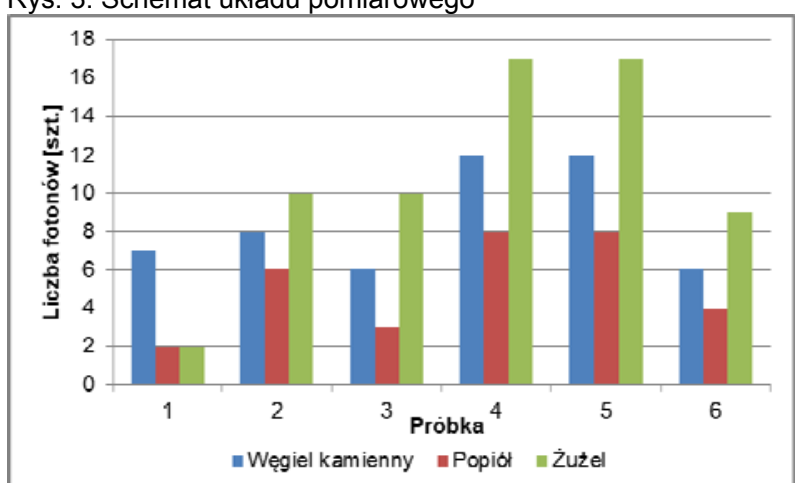

Rys. 4. Emisja fotonów w badanych próbkach węgla kamiennego i produktach spalania 


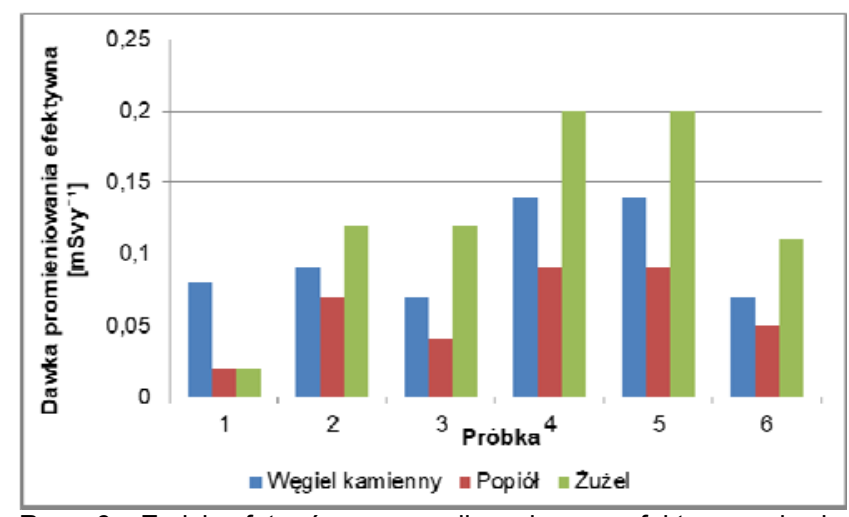

Rys. 6. Emisja fotonów w przeliczeniu na efektywną dawkę promieniowania w badanych próbkach węgla i produktach spalania

\section{Wyniki badań}

Rezultaty przeprowadzonych badań przedstawiono na rysunkach 4-6. Roczna efektywna dawka promieniowania węgla kamiennego zmienia się w zakresie 0,08-0,14 mSvy 1. Jest ona dwukrotnie wyższa niż wyniki otrzymane dla próbek popiołu. Zróżnicowana dawka promieniowania efektywnego dla żużla zmienia się w bardzo szerokim zakresie $0,02-0,20 \mathrm{mSvy}^{-1}$. Otrzymane wyniki badań wyraźnie wskazują na występowanie zależności pomiędzy zawartościami radionuklidów w węglu kamiennym oraz produktach spalania.

Zaabsorbowane dawki promieniowania gamma dla węgla kamiennego zmieniały się w zakresie 59,19-118,39 $\mathrm{nGyh}^{-1}$. Popiół powstały ze spalenia węgla odznacza się niższymi dawkami promieniowania gamma, podczas gdy żużel emituje dawki promieniowania nawet do 1,5 raza większe niż węgiel kamienny. Odnosząc uzyskane wyniki badań do obowiązujących w Polsce wymogów Rozporządzenia Rady Ministrów w sprawie dawek granicznych promieniowania jonizującego (Dz.U. Nr 20, poz. 168 z 2005 r.), można zauważyć, że badane próbki rozpatrywane pojedynczo nie niosą dla ludzi zagrożenia promieniowaniem. W przypadku pracy ze wszystkimi rodzajami próbek dawki promieniowania sumują się. Zgodnie z wytycznymi Rozporządzenia sumaryczna dawka promieniowania nie przekracza $50 \mathrm{mSvy}^{-1}$ i nie stanowi zagrożenia dla zdrowia ludzi. W przypadku sumarycznej dawki pochłoniętej promieniowania gamma, w przypadku próbek 4 i 5 przekracza ona dopuszczalny poziom ustawowy o $165 \mathrm{nGyh}^{-1}$, co stanowi przekroczenie dawki o $82 \%$ w skali roku.

Analiza emisji fotonów w badanych próbkach wykazała występowanie zróżnicowanych wartości (rys. 4). Stwierdzono statystycznie istotna większa liczbę fotonów w próbkach żużla niż węgla i popiołu. Dwukrotnie i półtorakrotnie wyższa emisja fotonów z żużla, co wynika z

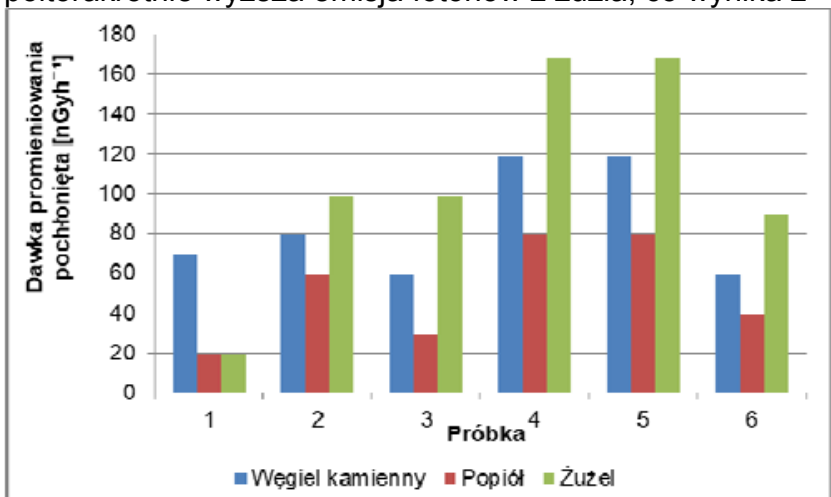

Rys. 5. Emisja fotonów w przeliczeniu na pochłoniętą dawkę promieniowania w badanych próbkach węgla i produktach spalania ich odmiennej entropii i metody wytwarzania. Istotnie na zawartość fotonów wpływa temperatura spalania węgla, ponieważ w przypadku popiołu odnotowano emisję fotonów na średnim poziomie 5 szt., a w przypadku żużla 11. Z przedstawionych danych wynika, że zmiana temperatury spalania węgla o ok. $350^{\circ} \mathrm{C}$ ponad dwukrotnie wzmaga przemiany promieniotwórcze pierwiastków zawartych w węglu kamiennym. Obserwowana emisja fotonów podczas badań miała charakter ciągły i nie zmienny w czasie pomiaru. Dla wszystkich analizowanych próbek stwierdzono statystyczne zróżnicowanie emisji fotonów podczas badań.

\section{Podsumowanie}

Przedstawiona metoda wykazała swoją użyteczność do uzupełniającej oceny promieniotwórczości węgla kamiennego oraz produktów pochodzących z jego spalania. Zastosowanie naturalnej luminescencji może być przydatna w ustalaniu wartości czynników wagowych tkanek i narządów człowieka, które są narażone na promieniowanie. $\mathrm{Na}$ świecie znane sa przykłady zastosowań emisji fotonów przez układy żywe m.in. do określania komórek nowotworowych, śledzenia transformacji energii w komórkach, analiz oddziaływania nanocząstek na organizmy $[15,20,21,22]$.

Występująca monotoniczna emisja fotonów, obserwowana we wszystkich próbach węgla (tab. 1) i popiołem węglowym (tab. 2) odpowiada obserwacjom przeprowadzonym przez Coyne'a [16] dla kaolinitów (w porównaniu z haloizytem i attapulgitem). Otrzymane wyniki potwierdzają również tezę Coyne'a, że fotony uwolnione z węgla wykazują dużo niższą intensywność niż obserwacje przeprowadzone dla kaolinitu, ale jest to zgodne $z$ wysoce pochłaniającym charakterem węgla.

Przeprowadzone doświadczenia wykazały również istotną zależność pomiędzy temperaturą spalania węgla a równowagą promieniotwórczą w poszczególnych produktach spalania. Osiagnięcie temperatury spalania węgla na poziomie $1100^{\circ} \mathrm{C}$ może powodować topnienie uranu i jego transpozycję do żużli. Wysoka temperatura spalania może również prowadzić do uaktywnienia izotopów polonu, talu i bizmutu, których pary osiadają na cząstkach popiołów, znacząco wpływając na ich promieniotwórczość. Opisane zależności potwierdzają wcześniejsze doświadczenia opisywane przez Michalika [23].

Autorzy: dr inż. Maciej Gliniak, Uniwersytet Rolniczy w Krakowie, Wydział Inżynierii Produkcji i Energetyki, Instytut Inżynierii Rolniczej i Informatyki, Al. Mickiewicza 21, 31-120 Kraków, E-mail: maciej.gliniak@urk.edu.pl; dr hab. inż. Jarosław Knaga, Uniwersytet Rolniczy w Krakowie, Wydział Inżynierii Produkcji $i$ Energetyki, Katedra Energetyki i Automatyzacji Procesów Rolniczych, Al. Mickiewicza 21, 31-120 Kraków, E-mail: jaroslaw.knaga@urk.edu.pl; dr inż. Marcin Tomasik, Uniwersytet Rolniczy w Krakowie, Wydział Inżynierii Produkcji i Energetyki, Katedra Energetyki i Automatyzacji Procesów Rolniczych, Al. Mickiewicza 21, 31-120 Kraków, E-mail: marcin.tomasik@urk.edu.pl; mgr inż. Anna Lis, Uniwersytet Rolniczy w Krakowie, Wydział Inżynierii Produkcji i Energetyki, Instytut Inżynierii Rolniczej i Informatyki, Al. Mickiewicza 21, 31-120 Kraków, E-mail: anna.lis@urk.edu.pl; mgr inż. Ernest Popardowski, Uniwersytet Rolniczy w Krakowie, Wydział Inżynierii Produkcji $i$ Energetyki, Instytut Eksploatacji Maszyn, Ergonomii i Procesów Produkcyjnych, Al. Mickiewicza 21, 31-120 Kraków, E-mail: epopardowski@gmail.com; Matylda Gliniak, Uniwersytet Jagielloński, Collegium Medicum, Wydział Lekarski, ul. św. Anny 12, 31-008 Kraków, E-mail: matylda.gliniak@gmail.com.

\section{LITERATURA}

[1] Niewęgłowska-Mazurkiewicz A. Ziemskie promieniowanie naturalne (promieniowanie skorupy ziemskiej, odpadów kopalnianych, materiałów budowlanych - intensywność, zawartość w różnych materiałach, szkodliwość), 
http://www.if.pw.edu.pl/ pluta/pl/dyd/mfj/zal03/nieweglowska/ PRACA-FJ(wstep, historia, definicje).htm

[2] Róg L. 2003. Wpływ budowy petrograficznej i chemiczne węgla kamiennego na temperaturę topliwości popiołu, Prace naukowe GIG, Górnictwo i Środowisko, 1, 73-96

[3] Róg L. 2004. Wpływ parametrów jakościowych na efektywność jego spalania. Materiały konferencyjne „Z węglem kamiennym ekologicznie i oszczędnie", Katowice, GIG, 5-15.

[4] Lorenz U., Blaschke W., Grudziński Z. 2002. Propozycja nowej formuły sprzedażnej węgla energetycznego przeznaczonego dla energetyki zawodowej. Wydaw. IGSMiE PAN, Studia Rozprawy Monografie, nr 112

[5] Sztaba K., Blaschke Z. 1996. O podstawowych uwarunkowaniach podnoszenia jakości koncentratów węglowych. Materiały z Konferencji Naukowo-Technicznej: Poprawa jakości węgla w programie dostosowania górnictwa węglowego do warunków gospodarki rynkowej, Prace Naukowe GIG, Seria Konferencje, nr 12

[6] Róg L. 1998. Budowa petrograficzna oraz własności frakcj gęstościowych wydzielonych z węgli kamiennych i antracytu, Prace Naukowe GIG, $\mathrm{nr} 830$

[7] Róg L. 1999. Ocena wpływu zmienności składu petrograficznego na właściwości chemiczno-fizyczne frakcji o różnej gęstości wydzielonych $z$ węgli typów 31.1, 32.2, 33 , 34.2, 35.1 i 36, Zeszyty Naukowe Politechniki Śląskiej, Seria: Górnictwo, 243, 111-126

[8] Pindel T. 2000. Źródła promieniotwórczości naturalnej w wybranych kopalniach węgla kamiennego GZW, praca doktorska, Katowice, Uniwersytet Śląski, Wydział Nauk o Ziemi

[9] Bonczyk M. 2013. A determination of the concentration level of lead ${ }^{210} \mathrm{~Pb}$ isotope in solid samples for the assessment of radiation risk occuring in coal mines, J. Sust. Min.,12, 2, 1-7

[10] Rao N.S., Sengupta D., Guin R, Saha S.K. 2009. Natural radioactivity measurement in beach sand along southern coast of Orissa, eastern India, Environmental Earth Sci., 59, 593-601

[11] Mahur A.K., Kumar R., Mishra M., Sengupta D., Prasad R. 2008. An Investigation of radon exhalation rate and estimation of radiation doses in coal and flyash samples. Applied Radiation and Isotopes, 66, 401-406

[12] UNSCEARE. 2000. Source and effect of ionizing radiation, United Nations Scientific Committee on the effect of Atomic Radiation, New York

[13] Ruth B., Popp F.A. 1976. Experimentelle Untersuchungen zur ultraschwachen Photonenemission biologischer Systeme, Zeitschrift für Naturforschung, 31c, 741-745

[14] Kiełbasa P., Dróżdż T., Nawara P., Dróżdż M. 2017. Wykorzystanie emisji biofotonów do parametryzacji jakościowej produktów spożywczych, Przegląd Elektrotechniczny, 1, 153-156

[15] Oziembłowski M., Dróżdż M., Kiełbasa P., Dróżdż T., Gạsiorski A., Nawara P., Tabor S. 2017. Ultra słaba luminescencja (USL) jako potencjalna metoda oceny jakości żywności tradycyjnej, Przegląd Elektrotechniczny, 12, 131134

[16] Coyne L., Lahav N., Lawless J.G. 1981. Dehydration-induced luminescence in clay minerals. Nature, 292, 819-821

[17] Coyne L.M., Lawless J.G., Lahav N., Sutton S., Sweeney M. 1981. Clays as prebiotic photocatalysts origin of life, w: Proc 6th Int. Conf. Int. Soc. for the Study of the Origin of Life (Y. Volman, ed.). Reidel, Dordrecht, Holland, 115-124

[18] Coyne L.M., Pollack G., Kloepping R. 1984. Roomtemperature luminescence from kaolin induced by organic amines, Clays Clay Miner. 32, 58-66

[19] Hessley R.K. 1989. Luminescence in coal and its relation to clay minerals, Clay Minerals, 24, 107-113

[20] Borc R., Jaśkowska A., Dudziak A., Ultrasłaba emisja fotonowa z układów żywych, (2015), Politechnika Lubelska

[21] Birtic S., Ksas B., Genty B., Mueller M.J., Triantaphylidès C. Havaux M. 2011. Using spontaneous photon emission to image lipid oxidation patterns in plant tissues, Plant Journal, 67, 1103-1115

[22] Hossu M., Ma L., Zou X., Chen W. 2013. Enhancement of biophoton emission of prostate cancer cells by $\mathrm{Ag}$ nanoparticles, Cancer Nanotechnology, 4, 21-26.

[23] Michalik B. 2006. Naturalna promieniotwórczość w węglu kamiennym i stałych produktach jego spalania, Karbo, 1, 212 